\title{
Midwifery Skills Block 6.C (Infection and Neoplasm in the Reproductive and Breast System)
}

\author{
Aldina Ayunda Insani $1^{*}$ Uliy Iffah $^{2}$ \\ ${ }^{1}$ Bachelor of Midwifery at Medical Faculty, University of Andalas, Indonesia \\ ${ }^{2}$ Bachelor of Midwifery at Medical Faculty, University of Andalas, Indonesia \\ *Corresponding author.Email: aldinaayundainsani@med.unand.ac.id
}

\begin{abstract}
Midwifery education uses a new paradigm, namely the Problem Based Learning (PBL) method. In connection with the era of the industrial revolution 4.0, the issuance of Permendikbud No. 109 of 2013 concerning the Implementation of Distance Education in university, technological advances in Universitas Andalas which already have a learning management system (LMS) platform for e-learning using the Moodle application called interactive learning (i-learn), as well as the Covid- pandemic situation. 19, then an update of the learning method is carried out, namely the Blended Learning system with the i-Learn application on Block 6.C. $24.4 \%$ of students still have a good category outcome. One of the solutions for blended learning is using demonstrations and videos and making jobsheets. The purpose of this study was to improve student learning outcomes in Block 6.C Midwifery skills by utilizing videos as well as the previous ones using face-to-face systems.

The research subjects were the intervention group (class 2017 students using the I-Learn application, video) and the control group (class 2016 students with a face-to-face system). The activity was carried out for 5 weeks and the 6th week an assessment was carried out for each topic of the $6 \mathrm{C} \mathrm{KK}$. Based on the research results, it was found that student learning outcomes had increased, most of them were categorized as brilliant, and there were no students who repeated the KK 6.C. Online learning is quite effective because it can be accessed anywhere and anytime. However, there are limitations in online learning, namely students are not well supervised during the learning process. Weak internet signal and high quota fees are challenges for online learning.
\end{abstract}

Keywords: blended learning, video, block 6C midwifery skills

\section{INTRODUCTION}

Midwifery education uses a new paradigm, namely the PBL (Problem Based Learning) method, where at the basic level students must master learning techniques and it is hoped that later they will be able to learn continuously throughout their lives. Students are also required to master information technology that can be applied by nantinha in lectures including communication in the field, from interpersonal communication to communicating with various parties (doctors, other health workers and other non-health workers) either verbally or nonverbally. Mastery of this basic level of education is absolute, because it is a prerequisite for a student to be able to continue learning at the next stage.

After participating in this module, it is expected that they will have a solid cognitive restructuring to be able to achieve core competencies which include a number of knowledge, skills and attitudes, namely lifelong learning skills, skills in communicating as a midwife candidate, understanding the moral, ethical and legal aspects of running the profession. ${ }^{1}$

In connection with the Covid-19 pandemic situation and taking into account the growing and increasing number of Covid-19 patients who tested positive nationally and the increasing number of Patients Under Supervision (PDP) in the West Sumatra Region, the leadership of Universitas Andalas and the Faculty of Medicine of Universitas Andalas decided to take policies in accordance with the Circular of the Chancellor of Universitas Andalas Number: 8 / UN.16.R / SE / 2020 concerning Campus Activities in the Context of Covid-19 Pandemic Alert and Circular of the Dean of the Faculty of Medicine, Universitas Andalas Number: 2055 / UN16.2 / SE / 2020 Regarding 
the Prevention and Control of Covid-19 in the Faculty of Medicine, Universitas Andalas, students of the Undergraduate Midwifery Study Program do not take direct / face-to-face lectures for the specified time, so the learning process in Block 6.C midwifery skills is carried out online or by using distance education. technology so that it still pays attention to achievement competencies that must be obtained by students. ${ }^{1}$

\section{Brief Description of Midwifery Skills}

Block 6.C Obstetrics Skills (Infection and Neoplasms in the Reproductive System and Breast (Gynecology Pathology)) is a compulsory subject that must be studied by semester VI students in the Undergraduate Study Program of Midwifery, Faculty of Medicine, Universitas Andalas. Students who take part in learning on block midwifery skills have the opportunity to understand the Information and Education Communication Skills Series which includes counseling for preconception and perimenopausal women, KIE Sadari and Patholigi Gynecology, Anamnesis Skills Series and Physical Examination in women with reproductive disorders and a series of procedural skills which includes activities to take vaginal smears for pap smears and IVA examinations. ${ }^{1}$ Thus mastery of material and clinical skills in Block 6.C is important, because it will provide provisions for students to provide midwifery care for infections and neoplasms in the reproductive system.

\section{Learning Objectives or Outcomes}

After all lecture activities and skills programs are completed, students are expected to have abilities including attitudes, general skills, and special skills (Care provider, Communicator, Community Leader, Decision Maker dan Manager). ${ }^{1}$

\section{RESEARCH METHOD}

\section{Learning Method Development}

Problem-based learning (PBL) is a learning strategy for students to learn together in a small group through two main learning activities, namely small group discussions facilitated by a tutor and independent learning. ${ }^{2}$

PBL is a form of student center learning (SCL) learning method that is more focused and structured. Unlike the pure SCL, students are given flexibility in determining the scope of the material being studied according to their interests. In PBL learning, the scope of learning is more focused and specific. The scope of learning in PBL is based on specific learning objectives that are detailed in the curriculum. The amount of time spent in the PBL process is also more limited than the amount of time spent on pure SCL. In pure SCL, students are given the flexibility to determine the amount of time they need to complete their inquiry, while in PBL students must complete the achievement of their learning objectives within the time frame determined by the educational institution. In pure SCL, students can work individually based on their respective interests, so that they do not depend on the learning outcomes of other students. Whereas in PBL, the achievement of learning objectives by a student can be influenced by the results of extracting information from their peers in small groups because the information obtained by each student will be discussed to perfect the knowledge they gain. ${ }^{3}$

Problem solving is not the sole objective of the PBL process. Problems or scenarios are used as a stimulus for the learning process to increase knowledge and understanding of the learning objectives set in the curriculum. So that PBL can also be used to facilitate students to gain basic knowledge. Thus, PBL not only facilitates the acquisition of problem solving skills, but also the acquisition of knowledge and understanding, and several other soft skills such as communication, teamwork, independence and responsibility for learning, sharing information and respecting others. ${ }^{3}$

\section{Scheming ${ }^{3}$ :}

a. The coordinator uploads the KK designator on ilearn which can be accessed by all students and KK instructors (lecturers).

b. Lecturers identify, determine, and classify learning objectives that will be discussed in each PBL learning session.

c. The lecturer arranges, chooses or looks for the right scenario to stimulate students to learn the learning objectives that have been set for each PBL session. Scenarios can be in the form of cases, film clips, pictures, news clips and others.

d. The lecturer estimates the schedule for the implementation of the 1 st $\mathrm{KK}$, the amount of independent study time needed to achieve all the learning objectives that have been set for the PBL session and the schedule for the implementation of the next KK.

e. The lecturer prepares a rubric for assessing student activity during the clinical skills process through a checklist.

f. The lecturer divides students into small groups which can consist of 8-9 students per group, each group is facilitated by a KK ionstructure.

g. The KK instructor must be a midwifery lecturer who can carry out the following roles:

1) Helping the head of the KK group maintain group dynamics. 
2) Ensuring groups are able to complete the learning objectives that have been set.

3) Ensuring that all students have done their job correctly

4) Conducting a KK demonstration that has been videotaped and opening a question and answer session or discussion for any material that has a video.

5) Student assignments are in the form of making jobsheets using existing tools in their respective places and looking for reading material that is in accordance with the KK.

6) Encourage students to evaluate their understanding of the material by asking questions, explaining the material in their own words.

7) Provide feedback to students regarding their participation in KK activities

\section{Student Assessment Development}

Development of a student assessment system that includes: process assessment, result assessment, selection of assessment techniques according to competency levels. ${ }^{2}$

\section{Learning outcomes}

Learning outcomes for affective, cognitive or psychomotor elements. The distribution of the final value expected is $>80$ (quality value $=\mathrm{A}$ ).

\section{Student response to the development of applied learning methods and assessment systems}

Student responses are carried out by filling in a questionnaire as an evaluation of the learning methods used in KK 6.C and it is hoped that it can improve student mastery of competence.

\section{RESULTS AND DISCUSSION}

\subsection{Sample Characteristics}

Respondents in this study were students of the Undergraduate Midwifery Study Program, Faculty of Medicine, Universitas Andalas. In this study, students were in the learning cycle stage of Block 6C T.A 2019/2020 Midwifery Skills, totaling 44 respondents.

\subsection{Lecture Result Blended Learning Midwifery Skills Guide 6.C}

The Block Coordinator together with the members have prepared a Midwifery Skills Handbook (Keterampilan Kebidanan) for $\mathrm{KK}$ instructors and students in the form of soft files and sent via email and WhatsApp media. The $6 \mathrm{C} \mathrm{KK}$ tutorial can also be accessed by students on the i-learn page with a web address http://fk.ilearn.unand.ac.id/course/index.php? categoryid $=1184$

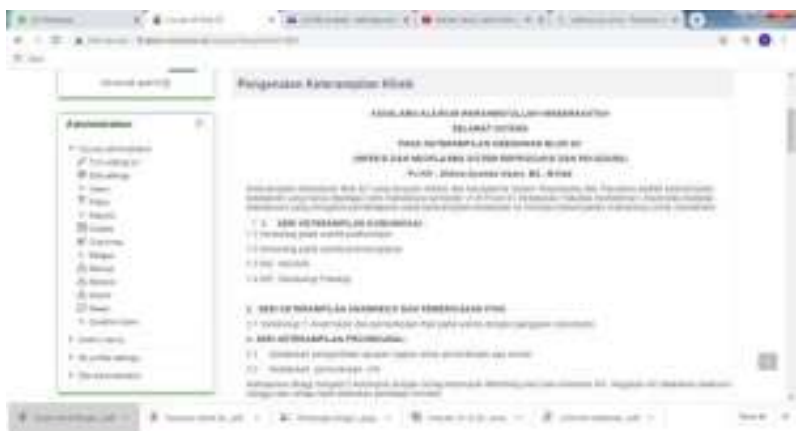

Figure 1. I-learn page for KK 6.C

\subsection{The Effect of Blended Learning and Video on Midwifery Skills 6.C Academic Year 2019- 2020}

Block 6C Midwifery Skills (Keterampilan Kebidanan) has a goal that students must be able to perform skills according to learning outcomes in the KK block. To determine the level of student ability, an assessment of each topic is carried out, namely an assessment of information and education skills related to the reproductive system, early detection of cervical cancer through the IVA test and Pap smear. Early detection activities include taking anamnesis and physical examination as well as informed consent.

Graphic Captions in Figure 2-7:

1. Strongly Disagree

2. Disagree

3. Agree

4. Stronglyagree

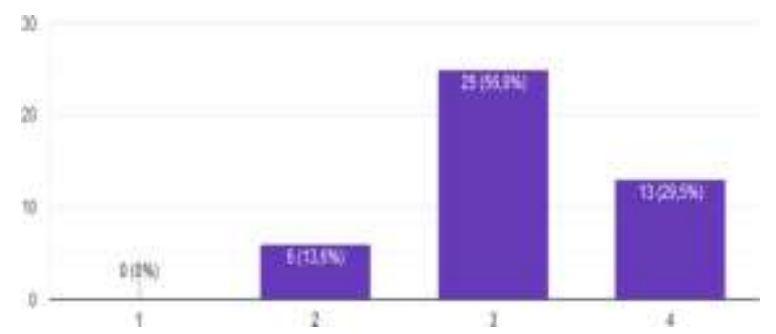

Figure 2. Evaluation of KK Lecturer-Student Communication 6.C

The majority of respondents stated that they had easy communication with lecturers to confirm $\mathrm{KK}$ activities, namely $56.8 \%$. 


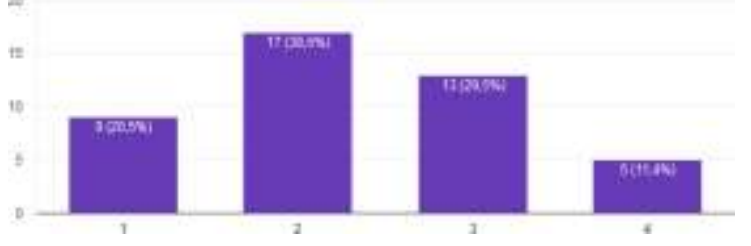

Figure 3. Evaluation Schedule KK 6C

The majority of respondents stated that the KK was not implemented according to schedule, namely $38.6 \%$.

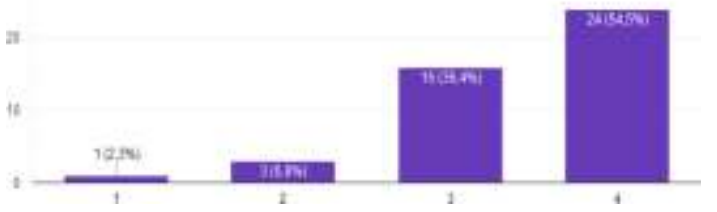

Figure 4. Suitability Evaluation of the Topic in the Guide to the Implementation of the $6 \mathrm{C} \mathrm{KK}$

The majority of respondents stated that the KK given was in accordance with the topics contained in the module, namely $54.5 \%$.

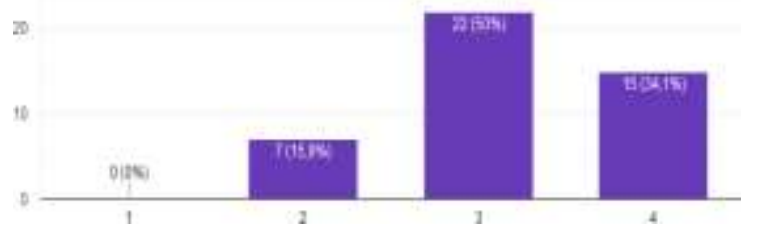

Figure 5. Evaluation of 6C KK Guidance by Instructors

The majority of respondents stated that the KK instructors were able to guide the clinical skills that students had to master, namely by $50 \%$.

According to research by Mendoza et al (2015), showing the effectiveness level of using instructional media such as video presentations as props for learning is very effective. because the use of media such as video enhances the teaching and learning process. The fact that visual media helps students retain concepts and ideas. $^{5}$

Additionally, there are a number of ways in which videos can make a real difference to the teaching and learning process in higher education. Some evidence suggests that the use of video-based learning can see improvements in teaching methods and learning outcomes. Research by Taslibeyaz et al (2017) shows that in the context of medical education from 2000 to 2014, especially case studies, it shows that watching videos is beneficial for gaining clinical skills, changing attitudes, encouraging cognitive learning, and retaining knowledge.6 Video learning offers flexible learning methods cost-effective and location-free, which are available at all times and can suit the individual needs of the learner, enabling them to study at their own pace and view material repeatedly if necessary. This is seen to have real benefits for students. In addition, the visual benefits of learning via video provide a means of increasing access to demonstrations of action / practice. Students can learn from field experts so they have the opportunity to see expert illustrations up close, and with the option of seeing them repeatedly if necessary. (Cooper and Higgins, 2015). ${ }^{7}$

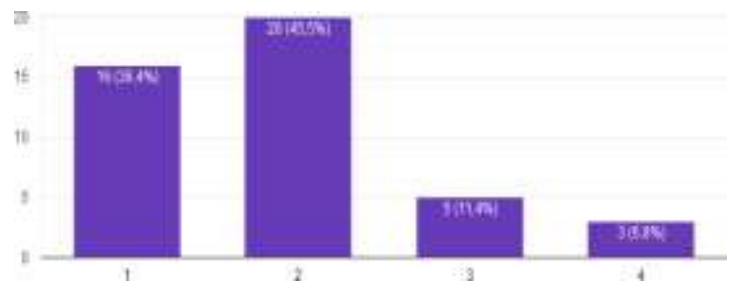

Figure 6. Evaluation of the Effectiveness of Online Methods at KK 6C

The majority of respondents stated that they did not agree that the method of online KK activities was more effective in achieving the skills that must be achieved, namely $81.9 \%$. This is in line with Mustakim's (2020) research which states that most students like face-toface learning, which is $46.6 \%$.

KK learning during the pandemic is conducted online. Online learning in Indonesia began in 2020 which was caused by global problems in the form of the 2019 Corona Virus outbreak (Pohan, 2020). This is done to prevent the transmission of covid-19. One of the things that must be considered during the Covid-19 pandemic is avoiding social gatherings and activities, and being close to other people (Kemenkes RI, 2020).

Online learning is better known as distance learning. Online learning is learning that takes place by utilizing the internet where the teacher and those being taught do not meet face to face directly (Pohan, 2020). Based on Anggrawan's research (2019) states that students with online learning are more successful in achieving learning outcomes compared to face-to-face learning students. Students with auditory and visual learning styles that are taught using the online learning model have an average value of learning outcomes that is superior to students who are taught using face-to-face learning models.

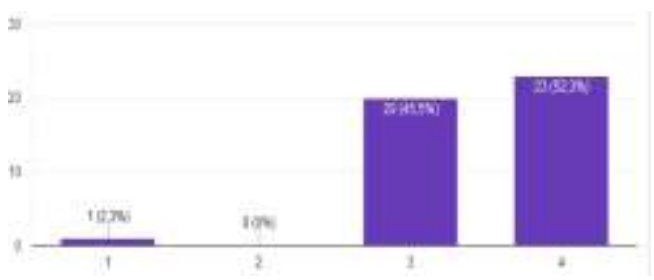

Figure 7. Evaluation of Topic Conformity with KK Instructor Guidance

The majority of respondents stated that the KK Instructor who guides according to what has been determined is $52.3 \%$. 
According to research by Stockwell et al (2015), video can provide a significant means to improve student learning and increase student engagement.8 Meanwhile, according to research by Rasi and Poikela (2016), video is used in a variety of ways to support various pedagogical strategies successfully. Not an exhaustive list, in the context of problem-based learning only, video clips can be used to present problems to students to trigger problem solving; to provide information on topics; or to present a solution to a problem at the end of the process. ${ }^{9}$

Cynthia's (2016) research, The prevalence of video use in higher education has increased exponentially over the past decade, and this trend is likely to continue in the future.10 The advancement of generations of students through higher education led to the emergence of new teaching methods (and the role of video in changing some in among others), the changing university environment, the development of digital media, and greater knowledge of the benefits of video in higher education will certainly contribute to this sustainable development. Furthermore, studies have shown that they can make a positive contribution to students' levels of self-confidence, motivation and performance. In each of these ways, the video is already showing the demonstrable impact of high levels of higher education.

But to maximize the benefits of educational videos it is important to remember three main components of cognitive load, elements that influence engagement, and elements that promote active learning. Fortunately, consideration of these elements converges with several recommendations (Cynthia, 2016):

- Make short videos and targeted at learning goals.

- Use audio and visual elements to convey appropriate parts of the explanation; consider how to make these elements complementary rather than superfluous.

- Use gestures to highlight important ideas or concepts.

- Use an enthusiastic conversational style to increase engagement.

- Embed videos in the context of active learning using guiding questions, interactive elements, or related homework assignments.

In addition, the rapid growth of video instruction in various contexts is accompanied by a wide range of design options available. This choice must consider the most appropriate content, style and platform to present the material, taking into account the best way to motivate students, improve learning outcomes and even consider students' affective (emotional) states to facilitate optimal learning (Chen and $\mathrm{Wu}, 2015) .{ }^{11}$

\section{CONCLUSION}

a. The majority of respondents stated that the KK given was in accordance with the topics contained in the module

b. The majority of respondents stated that KK instructors are able to guide the clinical skills that students must master

c. The majority of respondents stated that the KK Instructors who guide are according to what has been determined

d. The limitation in online learning is that students are not well supervised during the learning process. Weak internet signal and high quota fees are challenges for online learning.

\section{ACKNOWLEDGMENT}

This work was supported by LP3M University of Andalas, Medical Faculty and all of us at Bachelor of Midwifery Medical Faculty of University of Andalas.

\section{REFERENCES}

[1] Penuntuk Keterampilan Kebidanan Blok 6.C Prodi S1 Kebidanan Tahun Akademik 2019/2020

[2] Jupri, Wahab. 2017. Belajar dan Pembelajaran: Modal Dasar Menjadi Dosen Profesional. Bandung: Pustaka Reka Cipta

[3] Amir,M.Taufik. 2012. Inovasi Pendidikan Melalui Problem Based Learning. Jakarta: Prenada Media Grup

[4] Mendoza, G, L, L, et al. 2015. Effectiveness of Video Presentation to Students' Learning. International Journal of Nursing Science. 5(2): 8186. DOI: $10.5923 /$ j.nursing.20150502.07

[5] Obagah, R, R and Brisibe, W, G. 2017. The Effectiveness of Instructional Videos in Enhancing Learning Experience of Architecture Students inDesign and Drawing Courses: A Case Study of Rivers State University, Port-Harcourt. International Journal of Education and Research. Vol. 5 No.11.33 - 46. ISSN: 2411-5681.

[6] Taslibeyaz, E., Aydemir, M. and Karaman, S. (2017), 'An analysis of research trends in articles on video usage in medical education', Education and Information Technologies. 22(3), 873-881

[7] Cooper, D. and Higgins, S. (2015), 'The effectiveness of online instructional videos in the 
acquisition and demonstration of cognitive, affective and psychomotor rehabilitation skills', British Journal of Educational Technology 46(4), 768-779

[8] Stockwell BR, Stockwell MS, Cennamo M, Jiang E. 2015. Blended learning improves science education. Cell 162, 933-936.

[9] Rasi, P. and Poikela, S. 2016. A review of video triggers and video production in higher education and continuing education pbl settings. Interdisciplinary Journal of Problem-Based Learning 10(1).

[10] Cynthia J. B., 2016. Effective Educational Videos: Principles and Guidelines for Maximizing Student Learning from Video Content. Center for Teaching and Department of Biological Sciences, Vanderbilt University, Nashville, TN 37203. DOI:10.1187/cbe.16-03-0125

[11] Chen, C.-M. and Wu, C.-H. 2015. Effects of different video lecture types on sustained attention, emotion, cognitive load, and learning performance. Computers \& Education 80, 108- 121. 